\title{
The Influence of Diet Menus and Sports Models on Decreased Blood Sugar Levels and Body Weight in The Prediabetes Group
}

\author{
${ }^{1}$ Enda Silvia Putri, ${ }^{2}$ Rinawati Rinawati, ${ }^{3}$ Dian Fera \\ ${ }^{1}$ Public Health Faculty, Teuku Umar University, Meulaboh, Indonesia, endasilviaputri@utu.ac.id \\ ${ }^{2}$ Public Health Faculty, Teuku Umar University, Meulaboh, Indonesia, rinawati@utu.ac.id \\ ${ }^{3}$ Public Health Faculty, Teuku Umar University, Meulaboh, Indonesia, dianfera@utu.ac.id \\ Coresponding author : Enda Silvia Putri, e-mail : endasilviaputri@utu.ac.id
}

\begin{abstract}
Prediabetes was a condition where a person has abnormal blood sugar levels but was not yet categorized as diabetes (140-199 mg / dl). The increased incidence of prediabetes affects the increasing number of cases of diabetes, unhealthy diet and irregular exercise models are factors that cause weight problems and blood sugar levels that increase cases of prediabetes to have an impact on diabetes cases. The research purpose was the effect of diet menus and exercise models on reducing blood sugar levels and body weight in the prediabetes group. The method research was the analytical method with the design of quasi-experimental, the population was 20 people, and the sample was total population or sample of 20 people by dividing 2 groups with different interventions, the technique with accidental sampling, and tool with SPSS 20, the data analyzed with independent $t$ test. The result of research was the influence in group jasmine (diet and exercise menu (jogging) $(\mathrm{P}$ value $=0.001<\alpha=0.05)$, and in group rose (diet and exercise menu (casual walk) $(\mathrm{P}$ value $=0.004<\alpha=0.05)$ to reduce blood sugar levels and body weight. The conclusion of research was that the diet control and exercise menu models were able to influence the decrease in blood sugar levels and body weight in the prediabetes group, group a had a more significant effect because of jogging so that more calories burned.
\end{abstract}

How to cite this article: Putri, E. S., Rinawati, R., Fera, D. (2020). The Influence of Diet Menus and Sports Models on Decreased Blood Sugar Levels and Body Weight in The Prediabetes Group. JNS : Journal of Nutrition Science, 1(1), 1-5.

\section{Introduction}

Health problems in Indonesia are so complex, Indonesia is currently faced with a triple burden (three problems at once, namely the problem of old diseases re-emerging, comunicable diseases, and cronic diseases). cronic diseases every year have a fairly fluctuating number of cases. The number of cases of non-communicable diseases increases the number of cases and even dead in Indonesia. Degeneratif diseases are an increasing trend in cases such as hypertension, coronary heart, stroke, diabetec, and many others.(Budiarto \& Anggraeni, 2002; Kementrian Kesehatan Republik Indonesia, 2011; Lapau \& Birwin, 2017)

Diabetes Mellitus has a high prevalence of cases in Indonesia every year. Based on World data quoted from the International Diabetes Federation,

\section{ARTICLE INFORMATION}

Submitted: $07 / 01 / 2020$

Revised: $14 / 02 / 2020$

Accepted: 21/04/2020

Published Online : 15/05/2020

\section{Keywords:}

Prediabetes

Diet Menus

Sport Models
Indonesia ranks 7 th in the World with 8.5 million cases. In order 1-6 occupied by China with 98.4 million cases, India 65.1 million cases, America 24.4 million cases, Brazil 11.9 million cases, Russia 10.9 million cases, Mexico 8.7 million cases, Germany 7.6 million cases, Egypt 7.5 million cases, and Japan 7.2 million cases. The results of the Basic Health Research (Riskesdas) in Indonesia in 2013 showed the prevalence of diabetes cases $2.1 \%$ increased from $2007(1.1 \%)$ of the total 250 million population.(Internation Diabetes Federation, 2019; KEMENKES, 2018; Riskesdas, 2018)

This trend in diabetes cases is also followed by trends in prediabetes cases. Prediabetes is a condition in which a person is in the diabetes risk group but is not yet classified as diabetes. In the Riskesdas data, 2013 is called the TGT group (Disturbed Glucose 
Tolerance $=140-199 \mathrm{mg} / \mathrm{dl}$ ). Data on the prevalence of TGT cases in Indonesia is $29.9 \%$ or 52 million cases out of 250 million population. In 2018 the prevalence of cases has increased to $30.8 \%$. In Aceh Province the prevalence of prediabetes cases is increasing every year, in 2016 the prevalence of cases was $1.65 \%$, increased in 2017: $1.96 \%$, and increased again in 2018: 1.98\%.(KEMENKES, 2018; Riskesdas, 2018)

In West Aceh District, the research result of Putri's study, 2017 case of prediabetes in Johan Pahlawan Subdistrict. Based on data also obtained in several data centers in West Aceh diabetes always occupies the 10 most non-communicable diseases each year, as well as data from the Regional General Hospital in West Aceh DM cases also increase each year. Based on the Regency data, we can predict that the number of cases of prediabetes in West Aceh can be doubled or even more, looking at the number of cases of diabetes. The risk of a prediabetes seven times the likelihood of developing diabetes, so even though prediabetes data has not been collected, we can predict the number of diabetes cases.(Puskesmas Johan Pahlawan, 2018; Puskesmas Meureubo., 2017; Putri, Enda Silvia., Is, 2017; Rumah Sakit Umum Daerah Cut Nyak Dhien., 2018)

Increasing incidence of diabetes was to increase incidence of prediabetes, uncontrolled prediabetes causes the patient to end up in diabetes. Prediabetes is a diabetes risk group that must be taken seriously, because this group is able to return to normal blood sugar levels if consistent and ongoing prevention efforts are made. Prediabetes risk factors can be said to be the same as diabetes, such as diet, exercise, stress, obesity, cholesterol levels, and others. Putri's research results, 2017 showed that there were differences in the average blood sugar levels of the prediabetes group before and after hypertension $(\mathrm{P}$ value $=0.001)$. (Putri, Enda Silvia., Is, 2017)

Based on the problems that have been written, researchers are interested in examining the Effect of Diet Menu and Sports Model on Reducing Blood Sugar Levels and Body Weight in the Prediabetes Group.

\section{Method}

The research method used in this study is an analytic survey research method with a Quasi-Experimental design approach. The population in this study amounted to 20 people and the sample is a total sampling with the sampling technique is accidental sampling. A sample of 20 people was divided in two group, the name were Rose of 10 people and Jasmine of 10 people, both groups were given interventions, namely eating patterns according to the diets provided and sports models. The only difference is in the sports model, namely the jasmine group with the sports model (jogging) while the rose group with the casual walking sport model. This treatment was carried out for 3 consecutive months by following the diet and exercise models that have been designed by researchers. Research results were analyzed with TIndependent Test, tool used SPSS 22.(Notoatmodjo. S., 2015; Sugiyono, 2016)

\section{Results}

The research result that have been carried out after being analyzed bivariate with the T-Independent test show the following values.

\section{Difference in Average Blood Sugar Levels (BSL) and Body Weight (BW) Before and After Intervention in the Jasmine Group}

Table 1. Difference in Average Blood Sugar Levels (BSL) Before and After Intervention in the Jasmine Group

\begin{tabular}{llccc}
\hline \multicolumn{1}{c}{ Variabel } & N & Mean & Standar Deviasi & P Value \\
\hline BSL Before & 10 & 156.90 & 12.688 & 0.0005 \\
BSL After & 10 & 106.80 & 24.367 & \multirow{2}{*}{0.0505 . }
\end{tabular}

Based on Table 1. a significant $\mathrm{P}$ value is obtained ( $\mathrm{P}$ Value $=0.0005<\alpha=0.05)$ with interpretation there is a significant difference in blood sugar levels in the prediabetes group of jasmine from before and after the intervention.

Table 2. Difference in Average Body Weight (BW) Before and After Intervention in the Jasmine Group

\begin{tabular}{lcccc}
\hline \multicolumn{1}{c}{ Varaiabel } & N & Mean & Standar Deviasi & P Value \\
\hline BW Before & 10 & 58.30 & 13.639 & 0.028 \\
BW After & 10 & 54.70 & 10.034 & \\
\hline
\end{tabular}


Based on Table 2. a significant $\mathrm{P}$ value is obtained ( $\mathrm{P}$ value $=0.028<\alpha=0.05$ ) with intrepestation there is a significant difference in the weight of the prediabetes group of jasmine from before denga after intervention.

\section{Difference in Average Blood Sugar Levels (BSL) and Body Weight (BW) Before and After Intervention in Roses}

Table 3. Difference in Average Blood Sugar Levels (BSL) Before and After Intervention in the Rose Group

\begin{tabular}{lcccc}
\hline \multicolumn{1}{c}{ Variabel } & N & Mean & Standar Deviasi & P Value \\
\hline BSL Before & 10 & 157.80 & 13.919 & 0.0005 \\
BSL After & 10 & 110.30 & 21.965 & \\
\hline Based & &
\end{tabular}

Based on Table 3. a significant $\mathrm{P}$ value is obtained ( $\mathrm{P}$ value $=0.0005<\alpha=0.05$ ) with intrepestation there is a significant difference in the blood sugar levels of the rose prediabaetes group before and after the intervention.

Table 4. Differences in Average Body Weight (BW) Before and After Intervention in the Rose Group

\begin{tabular}{llccc}
\hline \multicolumn{1}{c}{ Variabel } & $\mathbf{N}$ & Mean & Standar Deviasi & P Value \\
\hline BW Before & 10 & 67.20 & 10.581 & 0.045 \\
BW After & 10 & 65.80 & 9.355 & \\
\hline
\end{tabular}

Based on Table 4. a significant $\mathrm{P}$ value was obtained ( $\mathrm{P}$ value $=0.045<\alpha=0.05$ ) with intrepestation there was a significant difference in the body weight of the rose prediabetes group before and after intervention

\section{Discussion}

The reseach result of bivariate analysis using the T-dependent test we can examine that as follows:

\section{Effect of Diet Menu and Sports Model on Decreasing Blood Sugar Levels and Body Weight in the Prediabetes Group of Jasmine}

The results in Table 1. show that $\mathrm{P}$ value $=$ 0.0005 which intrepretation that there was not same in blood sugar levels after before the intervention, meaning that the intervention (diet menu and exercise model (jogging)) is able to exert influence in reducing blood sugar levels in the Prediabetes Group of Jasmine.

The results in Table 2. show the same results, that is $\mathrm{P}$ value $=0.028$ which means there was a difference in body weight after before the intervention, meaning that the intervention (diet menu and exercise model (jogging)) is able to exert influence in losing weight in the Prediabetes Group . The $\mathrm{P}$ value of $\mathrm{BW}$ value of the Jasmine Predaibetes Group is smaller than the value of the Rose Prediabetes Group, this can be because the sports model (jogging) is more influential than the relaxed walk $(0.028<0.045)$.

Effects of Diet Menus and Sports Models on Decreased Blood Sugar Levels and Body Weight in Rose Prediabetes Group

The results in Table 3. show that $\mathrm{P}$ Value $=$ 0.0005 which explain that there ware not same in blood sugar levels after before the intervention, meaning that the intervention (diet menu and exercise model (leisurely walk)) can provide an influence in reducing blood sugar levels in the Prediabetes Mawar Group.

The results in Table 4. show that $\mathrm{P}$ value $=$ 0.045 which means that there is a difference in body weight after and before the intervention, meaning that the intervention (diet menu and exercise model (leisurely walk)) is able to influence the weight loss of the Rose Prediabetes Group

Effects of Diet Menus and Sports Models on Decreasing Blood Sugar Levels and Body Weight in the Prediabetes Group

Based on the results of Tables 1,2,3, and 4 show that dietary intervention and exercise models are able to influence the decrease in blood sugar levels and body weight in both prediabetes groups. Eating patterns in the form of a diet menu (balanced nutrition guidelines) and regular exercise (3 x 30 minutes a week) on many references such as according to nutritionists, health ministry and WHO from various research results show a very significant effect in controlling and even decreasing sugar levels blood and weight.(Eliana, 2015; Kemenkes RI, 2016, 2017; Kementrian Kesehatan RI, 2014; WHO, 2018)

The Frech study, 2017 conducted in Denmark in elderly women, concluded that there was an influence of physical activity with blood sugar levels in the prediabetes group. Imawati Research, 2017 conducted the practice of yoga exercises in the group of Type 2 DM patients and found the results there were differences in the effect of decreasing blood glucose levels in patients with Type 2 DM after yoga 
( $\mathrm{P}$ value $=0,000<\alpha=0.05)$. Imawati Research, 2014 in Yogyakarta with the type of yoga: Diayogarobik also has an influence on the decrease in blood glucose levels ( $\mathrm{P}$ value $=0,000<\alpha=0.05$ ). Wang's research results in China, 2017 only a high level of leisure physical activity ( $\mathrm{OR}=0.73,95 \% \mathrm{CI}$ : 0.57 , 0.95 ) has a protective effect against prediabetes. Conclusion. Free physical activity can be associated with a reduced risk of prediabetes.(Færch et al., 2017; Imawati, Kushartanti, Yogyakarta, Dinamometer, \& Dinamometer, 2014; Irmawati, 2017; Wang, Wu, Ning, Zhang, \& Zhang, 2017)

Shamizadeh Research in Iran, 2019. Promotion of effective physical activity interventions on blood glucose levels and body weight in the prediabetes group. Management education program has an influence on reducing blood sugar levels and body weight $(\mathrm{P}$ value $=0,000)$ based on Patimah research, 2017.(Patimah, Iin., Wahyudi, Iwan., Susyanti, 2017; Shamizadeh, Jahangiry, Sarbakhsh, \& Ponnet, 2019) Wieda Research, 2016 In prediabetes women aged 40-45 years it is known that the diet of kombucha tea can reduce blood sugar levels in the prediabetes group. Research Rock, 2014 in California stated the conclusion that there was a significant weight loss and control of blood sugar in a group of Type $2 \mathrm{DM}$ patients by following a food consumption management program. Ryu, 2018 in Seol, South Korea, the results of his research showed eating habits (vegetables and fruits) can reduce blood glucose levels in workers with prediabetes $(\mathrm{P}$ value $=$ 0.002). Magkos Research, 2017 An energyprudent diet, coupled with moderate physical activity, benefits some parameters of the metabolic syndrome and delays the onset of diabetes complications.(Magkos, Faidon., Yannakoulia, Mary., L.Chan, Jean., S. Mantzoros, 2017; Putri, 2016; Rock et al., 2014; Ryu, Moon, \& Jung, 2018).

\section{Conclusion}

Based on the research results obtained by intervening in the prediabetes group, it can be concluded as follows:

1. There is a significant effect of intervention (diet menu and exercise model (jogging) on decreasing blood sugar levels $(\mathrm{P}$ value $=0.0005)$ and body weight $(\mathrm{P}$ value $=0.028)$ in the Prediabetes Group of Jasmine.

2. There is a significant effect of intervention (diet menu and exercise model (casual walk) on decreasing blood sugar levels $(\mathrm{P}$ value $=0.0005)$ and body weight $(\mathrm{P}$ value $=0.045)$ in the Prediabetes Rose Group.
3. Jasmine Prediabetes Group is better in weight loss than Rose Prediabetes Group with a comparison of $\mathrm{P}$ value $(0.028<0.045)$, this can be interpreted as jogging is more influential than a relaxed walk in weight loss.

\section{Acknowledgement}

Acknowledgments, researchers presented to the Rector of Teuku Umar University, Research Institute, Community Service, and Quality Assurance of Teuku Umar University, Dean of the Publich Health Faculty-Teuku Umar University, Geuchik Village of Kampung Belakang, Village Apparatus of Kampung Belakang Village, all respondents who were residents of Kampung Belakang Village , the fiber of student of Publich Health Faculty who have contributed a lot so that this research can run well and be able to be written in journal form.

\section{Author Contribution and Competing Interest}

Author contribution in this research are involved in the design of research project, collecting data or analyzing result, involved in drafting or revising scientific papers.

\section{Publisher's Note}

JONS : Jurnal Of Nutritien Science remains neutral with regard to jurisdictional claims in published institutional affilition.

\section{References}

Budiarto, E., \& Anggraeni, D. (2002). Pengantar Epidemiologi. In EGC:Jakarta. https://doi.org/10.24252/idaarah.v2i1.5116

Eliana, F. (2015). Penatalaksanaan DM Sesuai Konsensus Perkeni 2015. SATELIT SIMPOSIUM 6.1 DM UPDATE DAN Hb1C.

Færch, K., Witte, D. R., Brunner, E. J., Kivimäki, M., Tabák, A., Jørgensen, M. E., ... Vistisen, D. (2017). Physical activity and improvement of glycemia in prediabetes by different diagnostic criteria. Journal of Clinical Endocrinology and Metabolism, 102(10), 3712-3721. https://doi.org/10.1210/jc.2017-00990

Imawati, I., Kushartanti, B. M. W., Yogyakarta, U. N., Dinamometer, P., \& Dinamometer, B. (2014). Jurnal Keolahragaan, Volume 2 Nomor 2, 2014. Jurnal Keolahragaan, 2(2), 182-193.

Internation Diabetes Federation. (2019). IDF Diabetes Atlas Ninth. In Dunia: IDF. 
Irmawati, I. (2017). Pengaruh Latihan Senam Yoga Terhadap Kadar Glukosa Darah Dan Kolesterol Pada Penderita Diabetes Mellitus Tipe 2. Jendela Olahraga, 2(2). https://doi.org/10.26877/jo.v2i2.1706

KEMENKES. (2018). Hasil Utama Riskesdas Tentang Prevalensi Diabetes Mellitus di Indonesia 2018. Hasil Utama Riskesdas Tentang Prevalensi Diabetes Melitus Di Indonesia 2018.

Kemenkes RI. (2016). Mari Kita Cegah Diabetik Dengan Cerdik.

Kemenkes RI. (2017). Buku Panduan GERMAS (Gerakan Masyarakat Hidup Sehat). In Warta Kesmas.

Kementrian Kesehatan Republik Indonesia. (2011). Penyakit Tidak Menular Penyebab Kematian Terbanyak di Indonesia, Jakarta. Depkes RI.

Kementrian Kesehatan RI. (2014). Pedoman PGSKesehatan,. Pedoman Gizi Seimbang.

Lapau, B., \& Birwin, A. (2017). Prinsip dan metode epidemiologi. In Prinsip dan metode epidemiologi.

Magkos, Faidon., Yannakoulia, Mary., L.Chan, Jean., S. Mantzoros, C. (2017). Management of the Metabolic Syndrome and Type 2 Diabetes Through Lifestyle Modification. PMC, HHS Public Access, 29, 223-256. https://doi.org/10.1146/annurev-nutr-080508141200

Notoatmodjo. S. (2015). Metodologi Penelitian Kesehatan. Jakarta: Rineka Cipta.

Patimah, Iin., Wahyudi, Iwan., Susyanti, S. (2017). Pengaruh Program Edukasi Manajemen Diabetes Mellitus (Promedia) terhadap Parameter Metabolik pada Pasien DIabetes Mellitus Tipe II di RSUD dr. Slamet Garut. Jurnal Medika Cendikia, 04(02).

Puskesmas Johan Pahlawan. (2018). Laporan Gizi Puskesmas Johan Pahlawan Tahun 2017. Meulaboh.

Puskesmas Meureubo. (2017). Data Sekunder Penyakit Tidak Menular. Meulaboh.

Putri, Enda Silvia., Is, J. M. (2017). Laporan Akhir Penelitian Dosen Pemula: Strategi Promosi
Kesehatan Dalam Penurunan Kasus Diabetes Mellitus di Aceh Barat. Laporan Akhir Penelitian Dosen Pemula.

Putri, W. D. (2016). Pengaruh Pemberian Minuman Teh Kombucha Terhadap Kadar Glukosa Darah Puasa Pada Wanita Usia 40 - 55 Tahun. 5(3), 207-213. https://doi.org/10.14710/jnc.v5i3.16401

Riskesdas. (2018). Hasil Utama Riskesdas Penyakit Tidak Menular 2018. Hasil Utama Riskesdas Penyakit Tidak Menular.

Rock, C. L., Flatt, S. W., Pakiz, B., Taylor, K. S., Leone, A. F., Brelje, K., ... Sherwood, N. E. (2014). Weight loss, glycemic control, and cardiovascular disease risk factors in response to differential diet composition in a weight loss program in type 2 diabetes: A randomized controlled trial. Diabetes Care, 37(6), 15731580. https://doi.org/10.2337/dc13-2900

Rumah Sakit Umum Daerah Cut Nyak Dhien. (2018). Data Sekunder Penyakit Tidak menular. Meulaboh.

Ryu, H., Moon, J., \& Jung, J. (2018). Influence of health behaviors and occupational stress on prediabetic state among male office workers. International Journal of Environmental Research and Public Health, 15(6), 1-13. https://doi.org/10.3390/ijerph15061264

Shamizadeh, T., Jahangiry, L., Sarbakhsh, P., \& Ponnet, K. (2019). Social cognitive theorybased intervention to promote physical activity among prediabetic rural people: A cluster randomized controlled trial. Trials, 20(1), 110. https://doi.org/10.1186/s13063-019-3220-z

Sugiyono. (2016). Metodologi Penelitian Kuantitatif, Kualitatif, dan R\&D. In CV Alfabeta. https://doi.org/https://doi.org/10.3929/ethz-b000238666

Wang, J., Wu, Y., Ning, F., Zhang, C., \& Zhang, D. (2017). The Association between Leisure-Time Physical Activity and Risk of Undetected Prediabetes. Journal of Diabetes Research, 2017. https://doi.org/10.1155/2017/4845108

WHO. (2018). Diabetes Programme. World Health Organization. 